\title{
Terveyskasvatus tutkimus- ja koulutusalana sekä arjen käytäntöinä
}

\section{JOHDANTO}

Terveyskasvatus on tieteellisenä tutkimusalana ja yliopistollisena koulutusalana verrattain nuori, mutta kansainvälisesti voimakkaasti kehittyvä instituutio. Arkikäytäntöinä terveyskasvatus on sen sijaan ollut aina läsnä inhimillisen kasvatustoiminnan yhtenä ilmenemismuotona. Ammatillisena haasteena sillä on myös jo pitkät perinteet. Esimerkiksi piirilääkäreiden ohjesäännössä vuodelta 1883 käy ilmi lääkäreiden kansansivistävä tehtävä terveyteen liittyvissä asioissa (Ohtonen 1983). Ammatillisen terveyskasvatuksen perinteisiä toteuttamispaikkoja ovat olleet $\mathrm{mm}$. lastenneuvolat ja kouluterveydenhuolto (Laitakari ym. 1989). Koulun opetussuunnitelmissa terveyskasvatuksen osuus on vuosikymmenten saatossa vaihdellut, mutta pitkät perinteet on sielläkin havaittavissa: ensimmäisiä terveyskasvatusaiheisia oppikirjoja käytettiin jo 1880-luvun lopulla (Kannas 1983).

Ammatillisen terveyskasvatuksen synnyttävänä sampona on toiminut terveystieteellinen yhteisö. Käyttäytymis- ja yhteiskuntatieteilijät ovat kiinnostuneet terveyskasvatuksesta voimallisemmin vasta parin viime vuosikymmenen ajan. He ovat kuitenkin merkittävästi myötävaikuttaneet terveyskasvatuksen teorianmuodostukseen ja tutkimuksellisen identiteetin tarkentumiseen.

Em. tieteenalojen suhdetta terveyskasvatukseen voidaan luonnehtia siten, että terveystieteet, eri- tyisesti lääketiede ja epidemiologia, määrittelevät pitkälti terveyskasvatuksen tavoitteina ilmaistut " toimeksiannot" ja käyttäytymis- ja yhteiskuntatieteellisestä teorianmuodostuksesta rakentuu terveyskasvatuksen toimintaa ja menetelmästrategioita ohjaava tietoperusta.

Perinteisesti terveyskasvatus on mielletty terveystieteitten piiriin kuuluvaksi. Yhtä lailla perusteita löytyisi myös sille, että terveyskasvatus ymmärretään yhtenä kasvatustieteellisenä sovellutusalana. Sen intressinä on kasvatusilmiöiden tutkiminen terveyden näkökulmasta, tai toisaalta terveyden edistämisen tutkiminen kasvatuksen näkökulmasta. Suomalaiselle terveyskasvatuksen asiantuntijayhteisölle on tyypillistä se, että kasvatustieteen edustajat eivät ole oivaltaneet terveyskasvatusta oman tutkimus- ja koulutusalansa repertuaariin kuuluvaksi. Terveyden edistäminen kasvatuksellisen keinoin tarvitsee kehittyäkseen huomattavasti voimakkaampaa kontribuutiota myös kasvatustieteiden piiristä. Tässä suhteessa Aikuiskasvatus-lehden oivallus terveyskasvatusaiheisen teemanumeron toimittamisesta on mitä tervetullein päänavaus. Silta kasvatuksen ja terveyden välille tarvitsee uusia ja uudentyyppisiä rakentajia lujittuakseen. 


\section{TERVEYSKASVATUS YLIOPISTON OPPIAINEENA}

Terveyskasvatuksen ainoat yliopistovirat ovat tällä hetkellä Jyväskylän yliopistossa, liikuntatieteellisen tiedekunnan terveystieteen laitoksella, missä terveyskasvatusta voi opiskella joko pääaineena tai sivuaineena. Terveyskasvatuksen dosentuureja on perustettu Jyväskylän ohella myös Kuopion ja Tampereen yliopistoihin. Alan ensimmäinen oppituoli perustettiin vuonna 1970 kehittämään liikunnanopettajien pedagogisia taitoja terveysopin opettamisessa sekä tehostamaan alan tutkimusta. Terveyskasvatuksen asiantuntijakoulutus käynnistyi vuonna 1984 terveyskasvatuksen suuntautumisvaihtoehdon muodossa. Opiskelijoina ovat terveydenhuoltoalan keskiasteen tutkinnon suorittaneet. Terveyskasvatuksen asiantuntijakoulutuksen perusopinnot johtavat terveydenhuollon kandidaattitutkintoon.

Vuonna 1990 terveyskasvatus sai Jyväskylän yliopistossa itsenäisen oppiaineen aseman. Eriytyminen ja irrottautuminen omaksi oppiaineeksi, tieteenalaksi noudattaa alan kansainvälistä kehitystä. Yhdysvalloissa terveyskasvatus on ollut yliopistollisena oppiaineena jo usean vuosikymmenen aikana, mutta Euroopassa alan akateeminen koulutus on laaja-alaisemmin käynnistynyt vasta 1980-luvulla. Terveyden edistämisen nykyiset ja tulevaisuuden haasteet, jotka on julkituotu mm. Maailman Terveysjärjestön ''Terveyttä vuoteen 2000" globaalisessa ohjelmassa, edellyttävät yhä enemmän sellaista erityisosaamista ja asiantuntemusta, jonka tuottajana ja kehittäjänä terveyskasvatuksen koulutuksella ja tutkimustoiminnalla on merkittävä osuus.

Terveyskasvatuksen akateemiset ovenpielet pyritään pitämään avoinna myös yliopiston ulkopuolisille opiskelijoille. Kesällä 1992 käynnistyivät ensimmäiset avoimen korkeakoulun järjestämät terveyskasvatuksen approbatur-kurssit. Yliopiston ulkopuolisista tahoista erityisesti UKKInstituutti järjestää runsaasti terveyskasvatuksen lyhytkurssimuotoista koulutusta. Se on myös tärkeä alan tutkimusyhteisö. Sosiaali- ja terveyshallitus tukee merkittävällä panoksella terveyskasvatuksen täydennyskoulutusta. Terveyskasvatusosaamisen kehittäminen on erityisen tärkeätä mm. terveystietoja opettaville opettajaryhmille, terveydenhuollon eri ammattiryhmille, kansanterveysjärjestöjen työntekijöille, sosiaali-, nuoriso- ja raittiustyöntekijöille, psykologeille, joukkotiedotusvälineiden terveysviestijöille, urheiluseurojen valmentajille.

\section{TERVEYSKASVATUSTUTKIMUS}

Terveyskasvatustutkimusta voidaan pitää soveltavana tutkimusalana, jonka tehtävänä on luoda tieteellinen perusta käytännön terveyskasvatustoiminnalle. Tutkimukselliset erityispiirteet soveltavan tavoitteen suhteen ovat siis pitkälti analogisia kasvatustieteelliseen tutkimukseen nähden (vrt. Hirsjärvi \& Huttunen 1991). Terveyskasvatustutkimus pyrkii selvittämään terveystieteistä nousevien "'toimeksiantojen'" edellyttämiä kasvatuksellisia tarpeita sekä niiden kasvatuksellisia ratkaisukeinoja. Terveystieteiden toimeksiannoilla tarkoitetaan sellaisia terveyteen ja sairauksiin liittyviä käyttäytymiseen, tottumuksiin, tapoihin' sekä psyykkisiin ja sosiaalisiin voimavaroihin liittyviä tekijöitä, joihin voidaan vaikuttaa kasvatuksellisin ja viestinnällisin keinoin terveyttä edistävästi. Terveyskasvatustutkimuksen intressinä on siis terveyden edistämisen kasvatuksellinen näkökulma. Toisaalta terveyskasvatustutkimusta voitaisiin jäsentää myös kasvatustieteen viitekehyksestä käsin. Tällöin tutkimuksen erityispiirteenä olisi kasvatuksen tutkimus terveyden näkökulmasta.

\section{TERVEYSKASVATUSTUTKIMUKSEN OSA-ALUEET}

Terveyskasvatustutkimuksen voidaan katsoa koostuvan seuraavista osa-alueista (Kannas 1988):

$\star$ Terveyskasvatuksen teoreettinen tutkimus

* Terveyskäyttäytymistutkimus

* Terveyskasvatuksen arviointitutkimus

- Terveyskasvatuskäytäntöjen tutkimus

- Terveyskasvatuksen kokeellinen kehittämistutkimus

* Terveyskasvatuksen yhteiskunnallinen tutkimus

Terveyskasvatuksen teoreettinen tutkimus selvittää $\mathrm{mm}$. terveyskasvatuksen filosofisia kysymyksiä, kuten esimerkiksi eettisiä ongelmia. Tutkimus pyrkii hahmottamaan terveyskasvatuksen teoreettista olemusta sekä kehittämään alan käsitteistöä. 
Terveyskäyttäytyminen (terveystottumukset, terveyteen liittyvät valinnat, päätökset, arvot, asenteet, tiedot, taidot) on keskeinen terveyskasvatuksen kohde ja siten myös terveyskasvatustutkimuksen omaleimaisuutta kuvaava tutkimuksen osa-alue. Terveyskäyttäytymistutkimus selvittää em. tekijöiden esiintyvyyttä eri väestöryhmissä; analyyttisempi tutkimus selvittää terveystottumuksia ja muita em. indikaattoreita sääteleviä psyykkisiä, sosiaalisia ja yhteiskunnallisia tekijöitä. Terveyskasvatuksen viitekehyksessä terveyskäyttäytymistä tutkitaan diagnostisesta näkökulmasta. Tiedonintressi on pitkälti instrumentaalinen eli tutkimuksen avulla pyritään arvioimaan terveyskasvatustarpeita, segmentoimaan ja rajaamaan mahdollisten interventioiden optimaalinen kohdejoukko jne.

Instrumentaalinen tiedonintressi ilmenee myös menetelmällisenä näkökulmana, jolloin tavoitteena on lisätä ymmärrystä esim. terveyskäyttäytymisen psyykkisistä ja sosiaalisista edellytyksistä. Näiden edellytysten tunteminen edesauttaa terveyskasvatuksen menetelmällisten strategioiden suunnittelua ja toteuttamista.

Terveyskäyttäytyminen on sisältövaliditeetiltaan ongelmallinen käsite. Se saattaa kapeasti määriteltynä rajata tutkimusalueen koskemaan vain tärkeimpien kansansairauksien riskitottumuksia (esim. tupakointi, liikunta, alkoholinkäyttö, ruokatottumukset). Laaja-alaisemman näkemyksen mukaan tutkimuksen kohteena olisi inhimillinen käyttäytyminen yleisemmin ja sen tarkastelu terveyden ja sairauden viitekehyksestä. Näin ollen terveyskäyttäytymistutkimuksen substanssia määrittelevät laajaalaisesti ne yhteisön tavat ja yksilöiden tottumukset, joilla on todettu olevan tai koetaan olevan merkitystä terveyden edistämisen sekä sairauksien ehkäisyn ja hoidon kannalta.

On esitetty myös perusteltuja epäilyjä terveyskäyttäytymistutkimuksen reviirin liialliselle laajentamiselle. Terveyden suurennuslasia tulisikin käyttää harkiten tutkimuskohteita valittaessa terveyskasvatustutkimuksen nimissä.

Terveyskasvatuksen arviointitutkimuksen tavoitteena on yhtäältä kuvata terveyskasvatuksen nykytilaa eri instituutioissa ja toisaalta tutkia suunniteltujen kokeiluohjelmien, kampanjoiden ja interventioiden toteutettavuutta, vaikuttavuutta ja tuloksellisuutta.
Arviointitutkimukseen kuuluva terveyskasvatuskäytäntöjen tutkimus kuvaa terveyskasvatuksen arkea toiminnan peruselementtien välityksellä; instituutiot, kasvattajat, kasvatettavat, oppimateriaalit. Eräät viestintätieteiden perinteiset tutkimuskohteet kuten esimerkiksi lääkärin/hoitajan ja potilaan vuorovaikutuksen tutkimus, joukkotiedotuksen terveyttä koskevan informaation sisällönanalyyttiset sekä terveyskasvatusmateriaalin vastaanottoa selvittävät tutkimukset voidaan lukea myös terveyskasvatuksen käytäntöjen tutkimukseksi. Terveysviestintä-käsite (health communication) onkin yleistymässä alan kirjallisuudessa kuvattaessa em. tyyppistä terveyskasvatusta.

Mainitut esimerkit osoittavat myös sen, että rajanveto eri tutkimuskohteiden tieteenalareviireiksi on usein varsin vaikeaa ja sopimuksenvaraista ja monesti turhaakin. Tieteenalan eriytymistrendistään huolimatta terveyskasvatustutkimus kuten muutkin tutkimusalat tarvitsevat laajan integroitumispinnan muiden tieteenalojen kanssa.

Terveyskasvatuksen kokeellisen kehittämistutkimuksen tehtävänä on arvioida suunniteltujen interventioiden ja kokeiluohjelmien toteutettavuutta, vaikuttavuutta ja tuloksellisuutta. Tutkimus on luonteeltaan kokeellista tai kvasikokeellista. Stufflebeamin (1976) arviointimallin mukaisesti tulisi myös terveyskasvatuksen interventiotutkimuksissa huomio kohdistaa tuotosarvioinnin ohella myös kehystekijöihin, panoksiin ja prosessiin. Prosessien tunteminen on välttämätön ehto tuotosten tulkinnalle. Tones (1988) kutsuukin osuvasti prosessia koskevia löydöksiä terveyskasvatuksen mustaksi laatikoksi.

Terveyskasvatuksen yhteiskunnallisen tutkimuksen kiinnostuksen kohteena ovat yhteiskunnallisten voimien ja kulttuuristen tekijöiden yhteydet terveyskasvatukseen. Tutkimuskohteena voisi olla esimerkiksi terveyspolitiikan tavoitteiden ja niiden toteuttamistapojen yhteydet terveyskasvatustoimintaan.

Kansantaloustieteellisestä näkökulmasta kiinnostava tutkimuskohde olisi $\mathrm{mm}$. terveyskasvatuksen ja siihen liittyvän koulutuksen yhteiskunnallisten hyötyjen ja kustannusten sekä hyötysuhteen tutkimus. Nupponen ym. (1991) ovat esittäneet yhtenä terveyskasvatustutkimuksen osa-alueena terveyskasvatuksen kulttuuritutkimuksen, jonka tutkimuksellinen viitekehys sisältää samoja 
elementtejä kuin terveyskasvatuksen yhteiskunnallinen tutkimus.

Terveyskasvatuksen kulttuuritutkimus antaa tietoa niistä kollektiivisista (kulttuurisista) mielikuvista, arvoista ja ajatustottumuksista, jotka heijastuvat sekä terveyskasvatuksen tuottamisessa että sen vastaanotossa.(Nupponen ym. 1991, Aarva 1991a). Terveyskasvatuksen historian tutkimus on eräs terveyskasvatuksen yhteiskunnallisen tutkimuksen erityisalue, jossa ilmenee kulttuurin tutkimuksen piirteitä.

\section{TERVEYDEN EDISTÄMINEN (Health Promotion)}

Terveyden edistäminen -käsite lanseerattiin voimallisesti 1980 -luvun alkuvuosina erityisesti Maailman Terveysjärjestön WHO:n toimesta. Tutkijat olivat kuitenkin käyttäneet tätä 'sateenvarjo"'-käsitettä jo aiemmin. Paljon käytetty on ollut mm. Greenin ja Anderssonin (1986) käsitteen määrittely:

"'Health promotion is any combination of health education and related organisational, economic and enviromental supports for behavior of individuals, groups or communities" (Green \& Andersson 1986, 516).

Terveyden edistämisen toiminta-alueet ovat tarkemmin eriteltynä seuraavat: Terveyttä edistävä yhteiskuntapolitiikka, terveellisen ympäristön aikaansaaminen, yhteisöjen ja kansalaistoiminnan kehittäminen, terveyspalvelujen kehittäminen ja terveyskasvatus (Ottawan asiakirja 1986, Nupponen ym. 1991, Vertio 1992)

WHO:n laatiman Ottawan asiakirjaa (1986) mukaellen terveyden edistämisen sisällöt voidaan tiivistää seuraavasti:

* Terveyden edistämisen kohteena on terveyden edellytykset; on vähennettävä vallitsevaa eriarvoisuutta.

* Kansanterveyden kehittyminen riippuu myös ympäristön terveellisyydestä.

* Terveyden edistämiseen sisältyy ihmisten sosiaalisten verkkojen ja sosiaalisen tuen vahvistaminen.

* Yhteisössä vallitseva elämäntapa ja yksilöiden terveystottumukset ovat terveyden edistämisen kannalta olennaisen tärkeitä.

* Tieto samoin kuin taito käyttää tietoa, koulu- tus sekä riittävät psyykkiset ja sosiaaliset voimavarat ovat terveellisten valintojen perusta.

Terveyden edistäminen on siis kokonaisvaltainen toimintastrategia, joka koostuu sekä terveyden yhteiskunnallisten, ympäristöön liittyvien sekä kasvatuksellisten edellytysten luomisesta. Terveyskasvatus on yksi terveyden edistämisen keinoista.

Vertio (1992) on todennut tuoreessa kirjassaan 'Terveyden edistäminen", että terveyden edistämisen toteutumisen kannalta olennaista on se, miten ihmiset tunnistavat, tuntevat ja hallitsevat oman elämänsä terveysriskejä. Näitä valmiuksia voidaan pitää myös keskeisinä terveyskasvatuksen tavoitteina.

\section{TERVEYSKASVATUS (Health Education)}

Terveyskasvatus on perinteisesti ymmärretty toiminnaksi, joka pyrkii sellaisten tottumusten, tietojen, asenteiden, arvojen ja taitojen omaksumiseen, joilla on terveydellistä relevanssia. Downie ym. (1991) antavat terveyskasvatukselle samansuuntaisen käsitteellisen sisällön:

"'Health education seeks to enhance positive health and to prevent or diminish ill-health, through influencing beliefs, attitudes and behaviour. The stimulation of a healthfull environment - social and political as well as physical - is an important objective" (Downie ym. 1991, 48)

Green ja Kreuter $(1991,17)$ korostavat omassa suppeassa määritelmässään, että terveyskasvatuksen tehtävänä on terveyskäyttäytymisen muuttaminen suunniteltujen oppimiskokemusten avulla.

Terveyskasvatuksen olemusta on toki kuvattu huomattavasti sävykkäämminkin. Tonesin ym.(1990) analyysi paljastaa, että on löydettävissä useita erilaisia terveyskasvatuksen lähestymistapoja, jotka heijastelevat erilaisia käsityksiä terveydestä, ihmisen olemuksesta ja kasvatuksesta samoin kuin oppimisesta. Suomessa mm. Shemeikka (1989) ja Nupponen ym. (1991) ovat esitelleet seikkaperäisemmin näitä Tonesin virittämiä terveyskasvatuksen lähestymistapoja. 
1. Traditionaalinen eli lääketieteellinen terveyskasvatus. Terveyskasvatuksen tavoitteena on suostutella yksilöitä omaksumaan elämäntyyli, joka ehkäisee sairauksia ja vähentää siten sairastavuutta ja kuolleisuutta. Lääketieteellistä terveyskasvatusta ohjaa pääasiassa somaattisiin tauteihin ja niiden ehkäisyyn liittyvä ajattelu. Taudit riskitekijöineen jäsentävät terveyskasvatuksen todellisuutta (ks. Heikkinen 1991).

2. Rationaalis-humanistinen lähestymistapa korostaa kasvatettavan rationaalisuutta ja vapautta tehdä itsenäisiä valintoja. Terveyskasvatuksen tehtäväksi riittää tämän lähestymistavan mukaan tietojen välittäminen ja arvojen selkeyttäminen, jotta tietoiset päätökset terveyden edistämiseksi mahdollistuisivat. Tavoitteena on siis terveydellisen yleissisivistyksen välittäminen vapaitten valintojen argumentaatioperustaksi.

3. Elämänhallintaa ja minän vahvistamista (self-empowerment) korostavassa lähestymistavassa terveyskasvatuksen tärkeinä tavoitteina nähdään ihmissuhdetaitojen oppiminen, eheän ja positiivisen minäkuvan luominen, itsetunnon vahvistaminen, sosiaalisten paineiden käsittelytaidon kehittäminen sekä terveyttä edistävien päätöksentekotaitojen parantaminen. Kannas (1985) on nimittänyt tätä lähestymistapaa myös psykososiaaliseksi terveyskasvatukseksi.

Terveyskasvatuksen menetelmälliset otteet ovat jäsentäneet siihen liittyviä alakäsitteitä. Melko vakiintunut käytäntö Suomessa terminologian suhteen on, että terveyskasvatuksen katsotaan toteutuvan valistuksena, opetuksena ja neuvontana. Terveysvalistus on joukkomittaista, yksisuuntaista lähinnä tiedotusvälineiden kautta toteutettavaa terveyskasvatusta. Sen sijaan koulun terveyskasvatus toteutuu pitkälti opetussuunnitelman ohjaamana opetuksena. Terveysneuvonta on tyypillinen terveyskasvatusmuoto erityisesti terveydenhuollossa. Terveyskasvatus toteutuu henkilökohtaisena vuorovaikutuksena, jossa pyritään ottamaan huomioon potilaan/asiakkaan tausta ja yksilölliset tarpeet (ks. Nupponen ym. 1991, Aarva 1991a).)

\section{TERVEYSKASVATUKSEN TEHTÄVÄT}

Terveyskasvatuksen lähestymistapoja kuvattaessa ilmeni jo, että terveyskasvatuksen keskeiset ta- voitteet ja tehtävät poikkeavat toisistaan riippuen lähestymistavasta. Niitä ei pidä kuitenkaan ymmärtää toisiaan poissulkevina. Terveyskasvatuskäytännöissä erilaiset toiminnalliset "filosofiat" toimivat parhaimmillaan toisiaan tukien. Eräänlaisena integroivana yhteenvetona terveyskasvatuksella voidaan nähdä olevan neljä suurta kasvatuksellista tehtävää:

* sivistävä tehtävä

* virittävä tehtävä

* mielenterveystehtävä

* muutosta avustava tehtävä

\section{Sivistävä tehtävä}

Terveyskasvatuksen hallitsevana ja siitä johtuen myöskin terveyskasvatus-käsitystä kapeuttavana tavoitteena on pidetty käyttäytymisen muuttamista. Muuttamis-ideologian dominanssin johdosta terveyskasvatuksen sivistystehtävä on jäänyt valitettavan vähälle huomiolle.

Terveyskasvatuksen sivistävä funktio perustuu tiedollisen terveyspääoman välittämiseen itseisarvoisena, sillä on arvo sinänsä. Tyypillistä terveyskasvatusajattelua on ollut nähdä tieto pääasiassa käyttäytymisen muutoksen renkinä. Tämä mekanistinen kausaalioletus ei toisaalta edes toteudu kovinkaan usein arjen empiriassa. Sivistysnäkökulmasta tarkasteltuna perustavat terveystiedot ja -taidot ovat osa yleissivistystä.

Erityisen kiintoisa sivistyksen sisällöllinen peili on peruskoulun opetussuunnitelma. Opetussuunnitelma kertoo kulloinkin, mikä on kansallisen sivistyksen ranking. Terveyssivistys ei ole koskaan yltänyt sille kuuluvaan asemaan opetussuunnitelmissa. Keväällä 1992 julkistettu opetusministeriön työryhmän esitys uudeksi tuntijaoksi haluaisi pyyhkäistä vähäisetkin terveyssivistävän oppiaineksen murut oppilaitten työpöydiltä.

Terveyskasvattajien olisi oikeutettua nousta tästä kapinaan ja vaatia terveyskasvatusta pikemminkin omaksi oppiaineeksi, kuten tilanne eräissä muissa maissa onkin. Lienee itsestään selvää, että yksi sivistyksellisen pääoman kivijalka muodostuu tiedoista ja taidoista, jotka koskevat omaa elimistöä, sielun maisemia ja näihin liittyviä terveyttä uusintavia ja kuluttavia tekijöitä ja niiden hallintakeinoja. Kuinka tämänkaltainen omaan elämänhallintaan ja terveyteen liittyvä yleissivistävä aines voisi olla vähämerkityksellisempää 
kuin opiskelu kuusta, tähdistä tai Rooman keisareista?

Erik Ablman (1976) jakoi tietämisen kahteen lajiin, sivistystietämiseen ja hallitsemistietämiseen. Tätä näkemystä voidaan soveltaa terveyskasvatuksenkin yhteydessä. Sivistävä terveyskasvatus pyrkii lisäämään ja jalostamaan sivistystietämistä tavoitteena ihmisen sisäinen kehittäminen. Tavoite ei ole samalla lailla instrumentaalinen kuin hallitsemistiedon osalta on. Hallitsemistiedon merkitys on sen sijaan keskeinen, kun tavoitteena on muuttaa omaa käyttäytymistä.

\section{Virittävä tehtävä}

Virittävän terveyskasvatuksen tehtävänä on stimuloida väestön, kohderyhmän tai -yksilön ajattelua ja keskustelua (ks. Hemanus ym 1987, Aarva 1991b). Eräiden tutkijoiden mielestä virittävyys tulisi rajata vain julkisen debatin ja poliittisten aloitteiden aikaansaamista tavoittelevaksi valistusstrategiaksi (Piispa 1982). Virittävä terveyskasvatus ei ole kiinnostunut käyttäytymisen muutoksesta vaan siitä, millaisia reaktioita sanoma synnyttää kollektiivisessa ja yksilöllisessä tajunnassa. Kyse on siis tietoisuusprosessien virittämisestä. Virtanen (1987) on tarkentanut virittävyystehtävän seuraavasti käyttäen esimerkkinä alkoholivalistusta:

"'Alkoholivalistuksen ei pidä pyrkiä käyttötapojen suoraan ohjaamiseen, vaan käyttötapoja ylläpitävien mekanismien - niin yksilöllisten, sosiaalisten kuin kulttuuristen - paljastamiseen, niiden näkyväksi tekemiseen. Painopisteen täytyy olla kysymyksessä miksi: miksi me käyttäydymme ja elämme niin kuin teemme, mitkä voimat meitä liikuttavat, millä tavalla voimme ottaa ohjat omiin käsiimme" (Virtanen, 1987, 32).

Virittävän terveyskasvatuksen tehtävän erityispiirrettä kuvastaa myös kasvattajan ja kasvatuksen kohteen välinen suhde. Aarva (1991b) on kutsunut kyseistä suhdetta virikesuhteeksi. Virikesuhteessa virittäviä terveysviestejä ei anneta alisteisuutta korostavan "käskysuhteen" puitteissa. Virittävä terveyskasvatus toteutuu aidoimmin silloin, kun ihmisille tarjotaan terveystematiikkaa käsitteleviä tietoisuutta stimuloivia ideoita ja näkökulmia vapaasti käytettäväksi.
Virittävä tehtävä voidaan nähdä myös osana laajempialaista oppimisprosessia. Virittävyys-idealla ja kognitiivisella oppimiskäsityksellä on tiettyjä teoreettisia yhtymäkohtia. Kognitiivisen käsityksen mukaan keskeinen lähtökohta oppimiselle muodostuu oppijan havaitessa aikaisemmat tietonsa riittämättömiksi tai ristiriitaiseksi uuden tiedon kanssa tai uudessa tilanteessa (Vaherva \& Ekola, 1987). Engeströmin (1984) mukaan keskeinen oppimisprosessia stimuloiva keino on ristiriidan virittäminen ja suuntaaminen opittavan asian oleellisiin tekijöihin. Tästä näkökulmasta virittävät terveyskasvatuksen sanomat ovat sellaisia, jotka saattavat vastaanottajansa epävarmuuden tilaan syntyneestä kognitiivisesta ristiriidasta johtuen. Kyse on siis eräänlaisesta urautuneen arkitietoisuuden rauhan rikkomisesta. Kun virittävästä valistuksesta keskustelevat tutkijat lopettaisivat tähän eli tyytyisivät virittävien miksi-kysymysten synnyttämiseen, niin kognitiivisesti suuntautuneelle oppimisprosessin ohjaajalle viritys olisi vasta alkusoittoa. Kognitiivisen oppimiskäsityksen mukaan olennaista terveyskasvattajalle olisi pyrkiä ristiriidan luomisen jälkeen myös auttamaan kasvatettavia rakentamaan ja jäsentämään uudelleen tämä kyseenalaistettu tietoisuus ja tietovaranto.

\section{Mielenterveystehtävä}

Terveyskasvatuksen mielenterveystehtävää tarkastellaan seuraavassa kahdesta näkökulmasta. Ensimmäiseksi mielenterveyden edistäminen on itseisarvoinen terveyskasvatuksen päämäärä. Käyttäytymisen muutoksia korostava terveyskasvatustraditio on sisältänyt hämmästyttävän vähän pohdiskelua siitä, minkälainen kasvatuksellinen haaste on vahvistaa terveyden psyykkisiä elementtejä.

Terveyskasvatus on kiinnostunut mielenterveydestä erityisesti ennaltaehkäisevässä mielessä. Tavoitteena on vahvistaa terveen kasvun psyykkisiä edellytyksiä kasvatuksellisin keinoin. Mielenterveyttä ei aloiteta, lopeteta tai ylläpidetä kuten terveystottumuksia, esimerkiksi tupakointia. Taipale (1992) on todennut, että nykyinen käsitys mielenterveydestä korostaa sen luonnetta uusiutuvana ja kuluvana voimavarana. Näin ollen terveyskasvatuksen mielenterveystehtävänä on edistää kasvatuksellisin keinoin ihmisten psyykkisten voimavarojen uusiutumista ja ehkäistä voimavarojen epätarkoituksenmukaista kulumista. 
Terveyskasvatuksen mielenterveystehtävää voidaan luonnehtia myös terapeuttiseksi näkökulmaksi kasvatukseen. Terapeuttista näkökulmaa terveyskasvatuksessa ei pidä sekoittaa ammatilliseen psykoterapiatyöhön. Nimitän tämän näkökulman toteutumista terveyskasvatuksessa arkiterapeuttiseksi kasvatus- ja viestintäotteeksi. Keskeisiä terveyskasvattajan arkiterapeuttisia taitoja olisivat siten $\mathrm{mm}$. vuorovaikutus- ja ihmissuhdetaidot, kuuntelemisen taito, myötäelämisen taito. Arkiterapeuttinen kasvatusote edellyttää herkästi ihmistä ymmärtävää psykologista lukutaitoa.

Toinen tarkastelutapa lähestyy mielenterveystehtävää instrumentaalisesta näkökulmasta käsin. Self-empowerment, minän vahvistaminen nähdään edellytyksenä terveyskäyttäytymisen muutokselle. Terveyskasvatuksen psykososiaalinen lähestymistapa perustuu juuri em. periaatteelle. Esimerkiksi tupakoinnin lopettamiseen tähtäävässä terveyskasvatusohjelmassa olennaisia tavoitteita on luoda positiivisempi minäkuva, lisätä itsetuntoa ja itseluottamusta sekä kehittää sosiaalisten paineiden käsittelytaitoja.

Terveyskäyttäytymisen muutos edellyttää tiedollisten ja taidollisten voimavarojen lisäksi runsaasti psyykkistä voimavaraa. Tämä voimavara voidaan ymmärtää muutoksen käynnistymistä ja toteutumista edellyttäväksi energiaksi. Energiakäsitteen käytölle löytyy tukea myös psykologiatieteen edustajilta. Mm. Vuorinen (1990) on todennut kiinnostavassa teoksessaan 'Persoonallisuus ja minuus", että psyykkisen työn kuvaaminen edellyttää energia-käsitteistön käyttöä. Tottumusten muutosprosessi vaatii runsaasti psyykkistä työtä, joka ilmenee mm. haluina, tunteina, tahtona. Kaikkiin näihin Vuorisen mukaan liittyy myös energeettinen puoli eli voimaa antava ja sitä kuluttava puoli.

Edelliseen viitaten terveyskasvatuksen tehtävänä voidaan nähdä tottumuksen muutosprosessin läpiviemiseen tarvittavan psyykkisen energian lisääminen. Terveyskasvatus on energian tuottamista. Toisaalta terveyskasvatuksen tehtävänä on myös vapauttaa sidottua energiaa. Taitava kasvattaja voi esimerkiksi ahdistusta lieventävillä menettelyillään vapauttaa merkittävästi kasvatettavan potentiaalista psyykkistä energiaa muutosprosessin käyttöön.

Energia-käsitettä on pohdittu hyvin vähän kasvatustieteellisessä kirjallisuudessa. Viinamäki
(1987) on psykiatrina soveltanut teoreettista viitekehystään terveyskasvatukseen. Viinamäen tutkimukset käsittelivät psykodynaamisen selitys- ja työskentelymallin soveltamista kahdenkeskiseen vuorovaikutukseen perustuvassa tupakoinnin lopettamisohjelmassa. Tutkimustulokset osoittivat, että tunteenomaisesti merkittävän vuorovaikutussuhteen syntyminen terveyskasvattajaan oli tärkeä tupakoinnin lopettamista ennustava tekijä.

Terveyskasvatuksen mielenterveystehtävä ja siihen sisältyvä terapeuttinen näkökulma kasvatukseen avaa monia kiinnostavia haasteita tutkimukselle, koulutukselle sekä käytännön terveyskasvatusmenetelmien kehittämiselle. On kuitenkin varottava sitä, että psyykkistä ei tuoda terveyskasvatuksen piiriin huolettomasti. Huoleton viittaa tässä yhteydessä viimeaikoina esiintuotuun psykokulttuuri-ilmiöön, jota Vuorikivi (1992) on ansiokkaasti hiljattain analysoinut. Hänen mukaansa psykokulttuurista on kysymys, kun arkitajunnan käyttöön valuu käsitteitä ja ajatusmalleja, jotka juontavat juurensa psykologisen ajattelun perinteestä ja etenkin sen popularisoinnista. Ongelmana arjen psykokulttuurisille ilmiöille on ohut tieteellinen argumentaatio.

\section{Muutosta avustava tehtävä}

Terveyskäyttäytymisen muuttamista on pidetty perinteisesti terveyskasvatuksen perustehtävänä. Kuten todettiin aiemmin, tämä on liian kapeaalainen näkemys terveyskasvatuksen tavoitteista. Kuitenkin se on keskeinen ja kuvaa olennaisesti toiminnan erityistä ominaislaatua.

Terveyskasvatusohjelmien vaikuttavuutta selvittävissä tutkimuksissa tottumuksissa havaitut muutokset ovat keskeisimmät interventioiden onnistumista osoittavia indikaattoreita. Muuttamistehtävässään terveyskasvatuksen intressi kohdistuu myös ns. välittäviin (ks.Tones ym.1990) tekijöihin kuten tietoihin, asenteisiin, arvostuksiin ja erilaisiin taitoihin. Tyypillisiä terveyskäyttäytymisen muutoksiin pyrkiviä terveyskasvatusesimerkkejä ovat mm. koululaisten tupakoinnin ehkäisyohjelmat, laihdutusinterventiot, diabeetikoille suunnitellut itsehoitokurssit, ensiapukurssit, ruokatottumusten muutoksiin pyrkivät yhteisötason terveyskasvatusohjelmat, turvavöiden ja pyöräilijöiden kypärän käytön lisäämiseen tähtäävät valistuskampanjat vain muutamia mainitakseni. 
Terveyskasvatukseen kohdistuneen kritiikin kärki on useimmiten kohdistettu sen vähäisiin ja lyhytaikaisiin käyttäytymisen muutosvaikutuksiin (esimerkiksi Liedekerken ym. 1990, Poikolainen 1989). Arvostetun skotlantilaisen terveyskasvatuksen tutkimusinstituutin (RUHBC, Research Unit in Health and Behavioral Change) tutkijaryhmä on kritisoinut sitä, että huolimatta käyttäytymisen muuttamistavoitteiden tärkeydestä terveyskäyttäytymisen muuttumista koskeva teorianmuodostus on heikosti kehittynyt (RUHBC 1989). Huolellisesti tehdyn katsauksen perusteella he kokosivat kolme teoreettista premissiä, jotka ilmenivät terveyskasvatusinterventioita kuvaavissa projekteissa ja tutkimuksissa. Ensinnäkin terveyskasvatusstrategiat heijastivat käsitystä, että ihminen on ensisijaisesti rationaalinen olento. Toiseksi sisäänrakennettuna teoreettisena oletuksena esitettiin, että saatuaan relevanttia terveysinformaatiota terveysongelmasta ja muutoksen toivottavuudesta ihmiset myös noudattaisivat annettuja terveyskasvatusohjeita. Kolmanneksi ilmeni, että terveyskasvatusohjelmissa huomioitiin vain vähäisessä määrin konteksti, missä terveyskäyttäytyminen toteutui.

Toisaalta on myös todettu, että terveyskasvatuksen tuloksellisuutta helposti aliarvioidaan. Karisto (1991) on huomauttanut, että väestössä terveyskäyttäytymismuutokset eivät useinkaan näy välittömästi, vaan vaikutukset kumuloituvat usein ajan myötä. Tästä syystä käyttäytymismuutoksia voi löytää sieltäkin, missä välittömiä vaikutuksia ei havaittu. Kokonaisuudessaan Kariston arvio terveyskasvatuksen onnistumisesta muuttamistehtävässään on kuitenkin melko varauksellinen.

Keskustelu terveyskasvatuksen vaikuttavuudesta jää usein pinnalliseksi siitä syystä, että muutosta ilmaisevien indikaattoreiden variaatiota ei olla analysoity riittävästi. Käyttäytymisen muutos ei ole ainoa muutostehtävän tavoite. Tutkimuksen tulisi kohdistua myös mm. terveyteen liittyvien mielikuvien, "terveyshaaveiden, -kokeilujen" ja minäkuvan muutoksiin

\section{LOPUKSI}

Terveyskasvatuksen tehtävät ovat varsin laajaalaiset. Edelläkuvattuja neljää suurta tehtävää ei pidä nähdä toisiaan poissulkevina. Esimerkiksi muutosta avustavan tehtävän tavoitteiden saa- vuttaminen edellyttää useimmiten muidenkin terveyskasvatuksen tehtävien toteutumista. Kuvatuista tehtäväalueista nousee mahdollisuus määritellä terveyskasvatuksen olemus ja tavoitteet uudella ja kokonaisvaltaisemmalla tavalla. Kokoavaksi määritelmäksi esitän seuraavaa:

"'Terveyskasvatuksen tavoitteena on kasvatuksellisin ja viestinnällisin keinoin tukea ihmisen tervettä kasvua ja selviytymistä, välittää sivistyksellistä terveyspääomaa sekä virittää terveyttä edistäviä muutostoiveita ja avustaa näitä muutospyrkimyksiä’'.

Terveyskasvatuksen asiantuntijalta edellytettävät valmiudet koostuvat terveyskasvatuksen tietoperustan eri osa-alueista. Nämä osa-alueet ovat näkemystieto, elämäntapatieto, kasvatustieto, kulttuuritieto ja terveystieto. Tietoperustan tarkempi analyysi on tehty toisaalla (ks. Kannas 1988). Mitkä ovat sitten terveystiedon asiantuntijuuden ohella terveyskasvattajan keskeiset osaamisen alueet? Nähdäkseni käytännön terveyskasvatustyössä toimivan tulee toimia viestijänä, opettajana, reportterina, arkiterapeuttina, kulttuurin tuntijana, suunnittelijana ja arvioitsijana sekä yhä useammin myös johtajana, managerina ja organisaattorina. Nämä toiminnalliset roolit kuvannevat riittävästi myös alan koulutuksen sisällöllisiä haasteita. 


\section{LÄHTEET}

Aarva, P. 1991a. Terveysvalistuksen kuvia ja mielikuvia. Acta Universitas Tamperensis, Ser A vol 328. Tampereen yliopisto.

Aarva, P. 1991b. Terveysvalistuksen kritiikki 1980-luvulla. Alkoholipolitiikka, 56(3): 199-210.

Ahlman, E. 1976. Kulttuurin perustekijöitä. Jyväskylä: Gummerus.

Downie, R.S., Fyfe, C., Tannahill, A. 1991. Health Promotion Models and Values. Oxford: Oxford Medical Publications. p. 48.

Engeström, Y. 1984. Perustietoa opetuksesta. Helsinki: Valtion painatuskeskus.

Green, L.W. \& Anderson, C.L. 1986. Community Health. St. Louis Times Mirror/Mosby College Publishing. p. 516.

Green, L.W. \& Kreuter, M.W. 1991. Health Promotion Planning. An Educational and Environmental Approach. Mountain View: Mayfield Publishing Company. p. 17.

Heikkinen, R-L. 1988. Laadullisen neuvonta-aineiston valottama terveyskasvatusanalyysi. Tampereen yliopiston kasvatustieteen laitos. Julkaisusarja A: Tutkimusraportti n:o 42, Tampere.

Hemanus, P., Partanen, J., Virtanen, M. 1987. Virittävyyden ongelma. Tampereen yliopisto, Tiedotusopin laitos, Julkaisuja Sarja C, 9/1987.

Hirsjärvi, S. \& Huttunen, J. 1991. Johdatus kasvatustieteeseen. Helsinki: Wsoy.

Kannas, L. 1983. Tupakointia koskeva terveyskasvatus peruskoulussa. Studies in Sport, Physical Education and Health 17. Jyväskylän yliopisto.

Kannas, L. 1988. Terveyskasvatustutkimus Suomessa 1970-80-luvulla. Teoksessa: Kannas, L., Miilunpalo, S. (toim.) Terveyskasvatuksen Vuosikirja 1988. Lääkintöhallituksen julkaisuja, Terveyskasvatus, Sarja Tutkimukset $8 / 1988$, Helsinki. s. 63-82.

Kannas, L. 1985. Psykososiaalinen opetusmalli ja sen soveltaminen terveyskasvatuksessa. Teoksessa: Laine, K. ym. (toim.) Terveyskasvatustutkimuksen Vuosikirja 1985. Lääkintöhallituksen julkaisuja, Terveyskasvatus, Sarja Tutkimukset 4/1985, Helsinki. s. 111-122.

Karisto, A. 1991. Tylsät hampaat vai sitkeä liha. Teoksessa: Terveyskasvatuksen neuvottelukunta (toim) Tylsät hampaat vai sitkeä liha? Terveellisten elintapojen edistäminen riskialtteimmissa väestöryhmissä. Sosiaali- ja Terveyshallitus, Raportteja 3/1991. s. 13-80.

Laitakari, J., Miilunpalo, S., Pasanen, M., Vuori, I. 1989. Terveyskasvatus terveyskeskuksissa. Lääkintöhallituksen julkaisuja, Terveyden edistäminen, Sarja tutkimukset 6/1989, Helsinki.

Liedekerken, P., Jonkers, R., de Haes, W., Kok, G., Saan,J. (eds) 1990. Effectiveness of Health Education. Assen: Van Gorcum.
Nupponen, R., Aarva, P., Laitakari, J., Miilunpalo, S., Paronen, O., Urponen, H. 1991. Terveyskasvatuksen taustakäsitykset ja vaikuttavuuden tutkiminen. Teoksessa: Urponen, H., Aarva, P., Nupponen, R. (toim.) Terveyskasvatuksen Vuosikirja 1991. Sosiaali- ja Terveyshallitus, Tutkimuksia 2/1991, Helsinki. s. 11-25.

Ohtonen, J., Koski,P., Vinni, K. 1983. Katsaus Suomen terveydenhuoltojärjestelmän kehitykseen. Suomen virallinen tilasto. Sosiaalisia erikoistutkimuksia. SVT XXXII:96, Helsinki.

Opetusministeriön työryhmien muistioita 1992:9. Tuntijakotyöryhmien muistio: Helsinki.

OTTAWA CHARTER for Health Promotion. 1986. Health Promotion 1 (1) iii - V.

Piispa, M. 1982. Virittääkö valistus? Tiedotustutkimus, 5(3): 41-50.

Poikolainen, K. 1989. Viestintä vaarantaa terveytesi. Duodecim 105(22): 1790-1795.

RUHBC 1989. Changing the Public Health. New Yourk: John Wiley \& Sons.

Stufflebeam, D. L. 1976. Evaluating the context, input, process and product of education. In: Tammivuori, T. (ed.) International Congress of Physical Education. Jyväskylä, June 28-July 3, 1976. Liikuntatieteellisen Seuran Julkaisuja 64, Helsinki. s. 15-22.

Taipale, V. 1992. Lasten mielenterveystyö. Helsinki: WSOY.

Tones, K. 1988. Selecting indicators of success in health education: the importance of theory and philosophy. Teoksessa: Kannas, L. \& Miilunpalo, S. (toim.) Terveyskasvatuksen Vuosikirja 1988. Lääkintöhallituksen Julkaisuja, Terveyskasvatus, Sarja Tutkimukset $8 / 1988$, Helsinki. s. $33-41$.

Tones, K., Tilford, S., Robinson, Y. 1990. Health Education. Effectiveness and efficiency. London: Chapman and Hall.

Vaherva, T. \& Ekola, J. 1986. Aikuisen opettamisen taito. Helsinki: Oy Yleisradio Ab

Vertio, H. 1992. Terveyden edistäminen. Helsinki: WSOY ja Sairaanhoitajien Koulutussäätiö. (painossa)

Viinamäki, H. Vuorovaikutustekijöiden merkityksestä terveyskäyttäytymismuutoksessa. Lääkintöhallituksen Julkaisuja, Terveyskasvatus, Sarja Tutkimukset 3/1987.

Virtanen, M. 1984. Valistuksen vaikutukset. Tiedotustutkimus, 7 (1): 12-17.

Vuorikivi, J. 1992. Psykokulttuuri. Helsinki: Hanki ja Jää.

Vuorinen, R. 1990. Persoonallisuus \& Minuus. Helsinki: WSOY. 